Algorithmic Warfare and the Reinvention of Accuracy

Lucy Suchman

Lancaster University, Lancaster, UK

Lucy Suchman 1.suchman@lancaster.ac.uk 


\section{Algorithmic Warfare and the Reinvention of Accuracy}

This article aims to integrate two interrelated strands in critical security studies. The first is mounting evidence for the fallacy of claims for precision and accuracy in the United States 'counterterrorism' program, particularly as it involves expanding aerial surveillance in support of operations of extrajudicial assassination. The second line of critical analysis concerns growing investment in the further automation of these operations, more specifically in the form of the US Department of Defense Algorithmic Warfare Cross-Functional Team, or Project Maven. Building upon generative intersections of critical security studies and science and technology studies (STS), I argue that the promotion of automated data analysis under the sign of artificial intelligence can only serve to exacerbate military operations that are at once discriminatory and indiscriminate in their targeting, while remaining politically and legally unaccountable.

Keywords: military; targeting; artificial intelligence; weapons

In April of 2017, the United States Department of Defense (DoD) announced a proposal for the Algorithmic Warfare Cross-Functional Team, code-named Project Maven (Deputy Secretary of Defense 2017). The announcement by then Deputy Secretary of Defense Robert Work asserted the urgent need to incorporate 'artificial intelligence and machine learning across [DoD] operations,' citing 'increasingly capable adversaries and competitors.' The urgency expressed in Work's call contributes to a wider, highly performative rhetoric announcing an inescapable artificial intelligence (AI) arms race, in which Russia and China are figured as the primary antagonists. Project Maven's aim, Work states in his memorandum, is 'to turn the enormous volume of data available to DoD in the form of full-motion video into actionable intelligence and insights at speed.' The plan as Work sets it out includes an initial project focused on the task of labeling data within full-motion video generated by US Unmanned Aerial System (UAS) surveillance operations, as a first step toward establishing the algorithms and computational infrastructures needed to automate 'object detection, classification, and 
alerts' in support of weapons targeting.

In the spirit of this special issue (see Bellanova et al forthcoming), my analysis of these developments works at the intersections of scholarship in critical security studies and in science and technology studies (STS), particularly as each is increasingly informed by feminist theory and research. More specifically, I read security studies scholarship on the militarisation of perception as, inter alia, a project of explicating how violent force figures a threat and finds its targets. Research in STS, commensurately, has been devoted to tracking developments in military technologies with the understanding that technologies incorporate not only objects but also subject positions, bodies, discourses, and material practices. A feminist sensibility, in turn, directs attention to how difference is enacted as an integral constituent of technologies of militarism, and with what consequences for the differential valuation of lives. ${ }^{\mathrm{i}}$

My approach to the question of how US militarism determines a threat begins with military discourses of 'situational awareness.' As a scalable construct, situational awareness can range in its reference from the moment-to-moment comprehension by a combatant of their immediate circumstances, to comprehensive geopolitical understanding as a basis for strategic military planning and operations. Crucially for my purposes here, situational awareness is considered by military analysts to be the prerequisite for action adherent to the laws of war. This applies most pointedly to the act of killing, including the critical process of identifying who or what comprises a legitimate target.

Despite military aspirations to perfect situational awareness, the latter continues to be subverted by the problem named within military doctrine as the 'fog of war' (Owens 2000; Davidson 2011). Project Maven can be read, in this context, as a recent instance of the recurring promise of a technological solution to that enduring problem. 
In the contemporary moment, fantasies of dissolving the fog of war and achieving perfect accuracy in threat identification are invested in expanding data infrastructures, which in turn compel further developments in the automation of data analysis. Accuracy of targeting has become a touchstone for claims to military legitimacy but also, I will argue, a construct that increasingly obscures more than it reveals.

My critique works from the premise that claims for accuracy, which justify new investments in automated targeting systems, are based on a systematic conflation of the relation between a weapon and its designated target on one hand, and the identification of what constitutes a (legitimate) target on the other. No amount of improvement in the precision of the first can address the growing uncertainties and obfuscations of the second. Insisting that they can is part of a campaign to deny the culpability of the US military in increasing reliance on ever more questionable forms of stereotypic categorisation of who constitutes a legitimate target, and the expanding temporal and spatial boundaries of what comprises an imminent threat. In the context of so-called counterterrorism operations, the sign of the uniformed combatant has been displaced by practices of identification largely reliant on racial/ethnic and behavioural profiling. The imminent threat, moreover, no longer requires any actual evidence that an attack on a specific person or interest of the US will take place, or is even planned. Simple association of an individual by the surveillance apparatus with a category of targeted persons defined to be a threat is enough. At the same time, the strategic vagueness of the trope of precision with respect to the grounds for targeting is matched by an associated lack of clarity in what exactly comprises AI, a figure that floats free of the specific and still highly conditional techniques of data analysis that it glosses, and the inseparability of those data analytics from politics. Both underwrite new levels of 
military technophilia while mystifying the questionable apparatuses of recognition on which these 'intelligent' systems rely, and which they further institutionalize.

I begin with a review of writings within critical security studies and STS relevant to a critique of what I call, following Mackenzie (1990), the reinvention of accuracy in algorithmically enabled weapon systems. I then turn to a more extended discussion of the problem of situational awareness, and accompanying proposals for machine 'recognition' as a technological solution. On this analysis, situational awareness can be understood as an apparatus of recognition. The apparatus in Barad's conception $(2007,171)$ is that which enacts a boundary or cut that delineates entities and articulates their differences. Considered within this frame, situational awareness is one among the many apparatuses through which the architecture of enmity is put in place and into practice within the imaginative and territorial geographies of American militarism. ${ }^{\text {ii }}$ These ideas are then drawn through the case of UAS infrastructures, particularly those technologies of data analysis that are animated by, and enabling of, the current revival of the field of artificial intelligence. This provides the context for my discussion of Project Maven and its successor projects in the form of increasingly automated weapon systems. I conclude with a reflection on the implications of a critical challenge to algorithmic warfare, understood as the strategic reinvention of technologically-determined accuracy, and as an apparatus designed to normalise unaccountable acts of extrajudicial assassination.

\section{Reinventing accuracy}

A generative precedent for the analysis of contemporary algorithmic warfare is available in critical scholarship on nuclear weapons systems from the 1980s. Within the 
field of STS, Donald Mackenzie's ground breaking book Inventing Accuracy (1990) offers a meticulous reverse engineering of the technosciences of inertial guidance integral to the US strategic nuclear missile program. In the case of long-range missiles, Mackenzie's aim is effectively to 'uninvent' accuracy as an indisputable fact by showing the rhetorical and material practices of its demonstration, and in that way to interrupt the assertions of precision and certainty so central to weapon systems development. He proceeds by showing the heterogeneous engineering of strategic doctrine, organisational relations, and infrastructures that together comprise the conditions of plausibility for nuclear deterrence. ${ }^{\text {iii }}$ Emphasizing the targeting of identified military installations, accuracy in the context of the strategic nuclear program focused on assuring that a missile fired from thousands of miles away would find its designated mark. Mackenzie's analytic strategy is to document the ineradicable uncertainties and artifice involved in the construction of evidence for missile accuracy through testing. Related arguments were mobilised in relation to the subsequent Strategic Defense Initiative (SDI), including the impossibility of testing under realistic conditions, and the difference between assurances that a technological system will act according to its specifications on one hand ('verification' in the case of computationally-based systems), and the validity of those specifications in relation to the world in which the system will actually operate on the other (Parnas 1985; Smith 1993). In the case of SDI plans for 'launch on warning,' the problem of threat recognition, particularly in the case of increasingly automated systems, became key. ${ }^{\text {iv }}$

Mackenzie's analysis provides an inspirational point of reference for questioning the recent reinvention of claims for accuracy in the case of UAS operations. Feminist security studies scholar Lauren Wilcox attends to the embodied production of 'targetable, killable bodies' in UAS, with particular attention to problematic translations 
of signals into data, and mapping of data to persons. Considering the killing of 23 unarmed Afghan citizens in the Uruzgan district by US forces in 2010, ${ }^{\mathrm{v}}$ Wilcox observes that 'greater accuracy of vision is unlikely to serve as a check on the mistakes of either algorithmic or visual analysis when the bodies are already perceived, or rather, felt to be dangerous' $(2017,20)$. Wilcox cautions against a mystification of the powers of algorithmically-informed war fighting, in favour of a close analysis of the racialised and gendered bodies that the drone apparatus articulates. In a related argument, Amoore has observed that ' $[\mathrm{t}]$ he decisions taken on the back of algorithmic calculations ... conceal political difficulty, even discrimination and violence, within an apparently neutral and glossy techno-science' $(2009,54)$. My analysis aims to build upon these arguments by looking more closely at investments (in all sense of that term) in what is at this point a largely speculative field of technological development, singularised under the sign of 'AI'. Before turning to those developments, however, I examine more closely the problem for which expanding technologies of data analytics are offered as a solution.

\section{Situational awareness and the fog of war}

Kindervater $(2017,33)$ proposes that there is an epistemological violence common to both surveillance and targeting, such that the move towards increasing automation of weapon systems, particularly the dream of 'overcoming human error as a path to truth and certainty,' is part of a wider desire for the instrumentalisation of knowledge in the service of control. Within contemporary military discourse, the instrumentalisation of knowledge in the service of control over the combat zone is named 'situational awareness,' a concept that tethers a lineage of rationalist thought to the aspirational 
future of algorithmic warfare. Situational awareness is conceptualised as a mode of human cognition involving accurate perception of a surrounding environment. That environment includes the potential presence of 'the enemy,' posited as a pre-existing population focused on violent action towards those constituted by the military as 'friends' vi The task for the soldier under this doctrine is to perceive the presence of the enemy, anticipate the threat that they pose, and respond. This focus on an imagined individual engaged in perception of their surrounding environment (whether from a position of command and control, or immersed in the 'front lines' of combat) is now supplemented by a discourse of the network, which erases the subjectivities of its constituent persons. Far from displacing the cognitivist and behavioural models that inform the psychology of the individual warfighter, however, that model is extended to strategic figurations of the network itself.

The problem for which situational awareness is the posited solution was described in the early $19^{\text {th }}$ century by Prussian military theorist Carl von Clausewitz, and subsequently named the 'fog of war' (1989/1832). That phrase gained wider popular recognition as the title of director Errol Morris' documentary about the life and times of former U.S. Defense Secretary Robert McNamara (Morris 2003). In the film McNamara reflects on the chaos of US operations in Vietnam. Those operations made clear that the reliance on a uniformed body that signals the difference between 'us' and 'them' marks the limits of the logics of modern warfighting, as well as of efforts to limit war's injuries. Fundamental to both military strategy and to the laws of armed conflict, the principle of distinction between combatants and those who are 'out of combat' presupposes the war fighter's ability to recognise the difference, and to act upon that recognition. ${ }^{\text {vii }}$ This conceptualisation binds contemporary approaches to 'enhancing' situational awareness through new technologies to military doctrine based in an ideal of 
a legible battlespace, and a fighting force subject to rational decision-making and operational control.

The most frequently cited authority on situational awareness is M.R. Endsley, former Chief Scientist of the US Air Force, who in the 1990s developed a model of situational awareness as the perception/decision/action loop first conceived in the cybernetic configuration of anti-aircraft weaponry and now reconfigured as complex, distributed systems. On Endsley's definition; 'Situational awareness ... is the perception of environmental elements and events with respect to time or space, the comprehension of their meaning, and the projection of their future status' $(1995,36)$. In an article titled 'Enhancing Situational Understanding through the Employment of Unmanned Aerial Vehicles,' Major Brad Dostal further expands this cosmic view (Kaplan 2006). Situational understanding, he writes is:

The ability to maintain a constant, clear mental picture of relevant information and the tactical situation including friendly and threat situations ... The RSTA [Reconnaissance, Surveillance, and Target Acquisition] elements must provide situational understanding of the operational environment in all of its dimensions - political, cultural, economic, demographic, as well as military factors $(2001,1)$. ${ }^{\text {vii }}$

At the same time that this formulation expands the frame of situational awareness, it also makes explicit the latter's role in the process of 'target acquisition,' more specifically within the apparatus of the UAS.

The apparatuses of recognition envisioned by military doctrine presuppose an independently existing 'situation' that can be comprehensively rendered as information. To challenge this ontology and the doctrine that it underwrites, I draw on the work of feminist STS scholar Karen Barad (2007), for whom 'the apparatus' takes on a more profoundly performative role in world making. Thinking through experiments in quantum physics, Barad's conception of the apparatus designates the arrangements through which entities become onto-epistemologically discernable. Specific apparatuses 
make possible specific, always contingent, 'agential cuts,' which enact what Barad articulates as the 'exteriority-within-phenomena,' the boundaries that delineate entities as separate and identifiably different (2007: 140). Importantly for the concerns of this paper, Barad's conception of the apparatus places the observer inextricably within, rather than outside of or separate from, the material-discursive practices of worldmaking that the apparatus enables. Read through this reconceptualisation, the principle of distinction enacted in weapon systems developed and deployed by the hyperdeveloped countries can be understood as incorporating military actors into ever more complex and convoluted apparatuses of recognition; sociotechnologies that are themselves implicated in generating the unfolding realities that they are posited to apprehend.

In 'Lethal Visions,' Bousquet proposes that 'under the conditions of modern warfare it is less the weapon that has come to serve as a prosthetic extension of the eye than perception itself which has been caught up in an unrelenting process of becoming weapon' $(2017,63) .{ }^{\text {ix }}$ In a series of writings that elaborate this premise, Gregory $(2011$, $2014,2015,2018)$ offers a highly detailed, critical reading of the networks that entangle air and ground forces in the operations of the US and its allies. ${ }^{\mathrm{x}}$ Examining the 2010 strike in the Uruzgan district of Afghanistan Gregory shows how a highly distributed, fragile and noisy network committed to the project of 'positive identification' of a threat to 'friendly' troops on the ground tragically misrecognized its target. Gregory writes:

Advocates have made much of the extraordinary ability of the full motion video feeds from Predators and Reapers to provide persistent surveillance ('the all-seeing eye'), so that they become vectors of the phantasmatic desire to produce a fully transparent battlespace. Critics - myself included - have insisted that vision is more than a biological-instrumental capacity ... Seen thus, these feeds interpellate their distant viewers to create an intimacy with ground troops while ensuring that the actions of others within the field of view remain obdurately Other $(2014,1)$. 
Hussain $(2013,31)$ expands this analysis to include sound as well, pointing out that the audio tracks of the drone silence life on the ground while the operators are immersed in noisy feeds from analysts and observers located in other parts of the UAS apparatus. ${ }^{\mathrm{x}}$

In his extraordinary ethnographic account of the banalities of target generation in service of Navy 'Special Operations Forces' in Iraq's Anbar province, Lindsay (2017) further illuminates the self-referential circuits of counterinsurgency intelligence. Rather than ensure accurate identification, Lindsay argues, targeting processes by the Special Operations Task Force of which he was a part reinforced a parochial worldview and served the bias of US special forces for 'direct action,' effectively fullfilling the mandate to produce targets to the detriment of an informed engagement with relevant actors on the ground. These investigations make clear that the conditions of transparency and rational control imagined in military doctrine are belied by the apparatuses of recognition through which militarism reproduces itself.

\section{Machine 'recognition'}

If situational awareness posits a pre-existing reality that is temporarily obscured and sees the disclosing power of information as a remedy, it is no surprise that in the current moment the longstanding military desire for a solution to the 'fog of war' is invested in expanded networking and data analytics. Figured increasingly under the mystifying trope of a singularized and unexplicated 'AI,' these technologies are promoted as increasing the accuracy of the process of overlaying schemes of categorization to life on the ground. Comprising primarily communications metadata, ${ }^{x i i}$ 'signals intelligence' increasingly takes the place of human intelligence for the targeting of aerial strikes, in areas of US operations in Afghanistan and Iraq, and in the areas of undeclared war 
fighting in Yemen, Somalia and Pakistan (Scahill and Greenwald 2014). The ability to accumulate massive amounts of data is accompanied, however, by the debilitating challenge of rendering data into 'actionable' information. In the context of entrepreneurial capital, this problem is translated into an opportunity for businesses that promise to develop templates through which the work of finding patterns in data renderings can be automated.

Inspired by the use of predictive data analytics in the context of finance, marketing and consumer behaviour, a growing number of companies now offer technologies for 'pattern of life' analysis in counterterrorism operations (Bell 2013). In an article in The Intelligencer ${ }^{\text {xiii }}$ titled 'Activity Based Intelligence: Understanding the Unknown,' Letitia A. Long, then Director of the US National Geospatial-Intelligence Agency, sets out the logics of ABI and argues for its virtues (Long 2013). Enabled by 'the shift from traditional reconnaissance to the persistent surveillance that the demands of irregular warfare have driven since the September 11, 2001 attack,' and in the context of the 'global war against terrorism' (8), Long explains:

Intelligence gathering is like looking in a global ocean for an object that might or might not be a fish. It might be anything and it might be important, but at first, we are not sure it even exists. And whatever it might be is constantly moving and interacting with a huge number of other objects. They might make up an organized school of fish or they might not be related at all. But we do know that we need to find it, identify what it is, and figure out how it relates to all the other objects - whether fish or sea fowlwe either know or think might be important (8).

Imagined as a kind of naturalist project, Long's oceanic metaphor posits the existence of an environment inhabited by 'objects,' the identities and relevance of which for the observer are, however obscured, self-evident once discovered. At the same time, she observes:

The flood of full-motion video (FMV) data streams from unmanned airborne vehicles (UAV), the explosion in open source data from social media on the Internet, and the huge increase in requirements from special 
operations forces in Afghanistan and Iraq drove the massive expansion in the amount of data that can provide actionable intelligence (8).

Faced with potential threats whose 'signatures are weak,' in part due to the very volume and noise of the expanding surveillance infrastructure introduced to detect them, analysis of data, Long admits, could be 'overwhelming.' This hint of the possibility that those infrastructural investments might amount to an intelligence apparatus that is unusable is forestalled, however, by the invocation of ABI. The strategy of ABI is to 'maximize the value of "Big Data",' to enable recognition of adversarial patterns of life and social networks (Long 2013, 7). Long quotes Edwin Tse, Chief Technologist, Ground Systems Business Unit, Northrop Grumman Information Systems, who in a PowerPoint Presentation on ABI writes:

In environments where there is no visual difference between friend and enemy, it is by their actions that enemies are visible. Motion is the first indication of activity. Temporal and visual patterns of change provides (sic) the context for intent (cited in Long 2013, 7).

The convenience of this proposition for technologies of data analytics should be obvious. Building upon a discourse of situational awareness as attunement to anomalous shifts in what comprises a 'normal' scenery of places, persons, and activities, in this apparatus of recognition activity is translated into movement, and movement into machine readable changes across the frames of full motion video. Defining activity as normative patterns of movement over time translates life worlds inaccessible to observation from above to phenomena nicely tuned to the capacities of algorithmically structured processes of 'pattern recognition.' Long concludes with the assertion that 'ABI, while not an analytic panacea, can contribute to decisive planning and successful operations in any mission where the customer faces critical questions that discovering that which is concealed or unknown can answer' $(10) .{ }^{\text {xiv }}$ 
Long's claims for the revelatory powers of activity-based analysis are challenged, however, by mounting evidence for its in/discriminate effects. An analysis of so-called 'precision' air strikes carried out by the US and Coalition military in Pakistan from 2004 through 2015 by the Bureau of Investigative Journalism documents 3,341 fatalities from every known UAS attack during that period. ${ }^{\mathrm{xv}}$ Of those, 190 or $5.7 \%$ of victims were positively identified as 'children,' and 534 or $16 \%$ were identified as 'civilians'. xvi Along with these deaths granted the status of 'collateral damage' are the 52 people, or $1.6 \%$ of those killed, who were positively identified as so-called high profile or high value targets. And finally we are left with the remainder, the 2,565 people, or $76.7 \%$ of those killed, categorized simply as 'other'. This calls into question statements like that offered by Obama's Assistant to the President for Homeland Security and Counterterrorism John Brennan:

With the unprecedented ability of remotely piloted aircraft to precisely target a military objective while minimizing collateral damage, one could argue that never before has there been a weapon that allows us to distinguish more effectively between an al-Qa'ida terrorist and innocent civilians (2012, 1)

As the timeline from 2015 continues, the problem intensifies. The Bureau of Investigative Journalism reports that US 'counter terror' airstrikes have doubled since Trump's inauguration, targeting particularly Somalia, Yemen, and Afghanistan. In March of 2017 parts of both Somalia and Yemen were declared areas of active hostilities,' exempting them from targeting rules brought in by Obama to prevent civilian casualties. At the same time, the level of secrecy around these extrajudicial assassinations has increased. This evidence suggests that the automation of data analysis under the sign of artificial intelligence can only serve to exacerbate military operations that are at once discriminatory, in their reliance on profiling and other techniques of prejudicial classification, and indiscriminate, in their failures to adhere to International 
Humanitarian Law or any other forms of political or legal accountability.

\section{Project Maven}

In the summer of 2018 the problems of UAS visualities came under new public scrutiny thanks to a small but significant rebellion on the part of Google employees against the company's participation in Project Maven. Routed through a Northern Virginia technology staffing company called ECS Federal, Google's participation in the project remained quiet until debate on an internal company mailing list was reported in the media in March of 2018 (Conger and Cameron 2018, Fang 2018). As the wider Google community and the public learned, beginning in late 2017 Google's Project Maven contract was aimed at automating the labeling of video images captured on drone cameras for evidence of 'objects' of interest, as input to Air Force targeting operations. Despite protests on the part of Google spokespeople that the seeing to be automated by the project concerns classes of objects and 'non-offensive uses only' (Bergen 2018), it soon became clear that the objects of interest include vehicles, buildings and indeed humans on the ground.

Framed as a technical problem of image analysis, little detail is publicly available on just what the Project Maven apparatus aims to recognize. ${ }^{\text {xvii }}$ Academic researchers who joined in support of the insurgent Googlers in May of 2018 pointed out that further automation of the scopic regimes of the US drone program can only serve to worsen an operation that is already highly problematic, even arguably illegal and immoral under the laws and norms of armed conflict (Suchman et al 2018). On June 1 of 2018, Google announced that it would not renew the contract when it ended in March of 2019. And on June 7, 2018, Google Cloud CEO Diane Green announced the release 
of a set of AI Principles, which included the statement that the company would not provide AI technologies for use in weapon systems (Google nd). ${ }^{\text {xviii }}$

The resistance in the tech community was summarized plainly by former Chair of Google's parent company Alphabet and current Chair of the Defense Innovation Board Eric Schmidt, in a keynote address at the Center for a New American Security's Artificial Intelligence and Global Security Summit in November of 2017. ${ }^{\text {xix }}$ Schmidt cites resistance to Project Maven as 'a general concern ... of somehow the militaryindustrial complex using their stuff to kill people incorrectly' (Scharre et al 2017). 'Killing people correctly' under the laws of war requires adherence to the Principle of Distinction and the identification of an imminent threat, and as noted above, the legality of current US military operations in this regard is highly contested. Schmidt himself explains the problem of machine learning when applied to the 'abnormal':

But the other thing that's worth saying is that these algorithms, at least today, require a great deal of training data. And when I say a great deal I mean like, millions of entries in the matrices, billions of pieces of data. So the classic example: people would say "well why can't you figure out terrorism?" Well the good news is terrorism is very rare. Right? So it's much, much harder, if you will, to apply AI to that problem. Whereas trying to understand traffic, right? As an example of something that occurs every day, is far, far easier because you have so much training data (Scharre et al, 2017).

These reservations notwithstanding, Schmidt cites Project Maven approvingly, as a project that 'combines a lot of these very clever systems under a General named Shanahan, it's very clever' (Scharre et al 2017). ${ }^{\mathrm{xx}}$ And while the exact nature of the targets of analysis under development in the project remains unclear, at least the imaginary of an apparatus for the recognition of a terrorist threat continues to circulate. As one indicative example, Fortune magazine, in an article titled ' 3 Ways AI is Making You Safer,' reports that 'Project Maven, the Pentagon's most high-profile AI initiative, aims to use machine-learning algorithms to identify terrorist targets from drone footage' 
(Fortune Staff 2019). The Project Maven contract has since been assigned to Anduril Industries, whose CEO Palmer Luckey comments that 'practically speaking, in the future, I think soldiers are going to be superheroes who have the power of perfect omniscience over their area of operations, where they know where every enemy is, every friend is, every asset is' (Fang 2019), as well as data analytics firm Palantir, best known for its role in the Cambridge Analytica scandal (Greene 2019; Confessore and Rosenberg 2018).

Promoters of Project Maven summarize its aims as the use of artificial intelligence capabilities to render the analysis of drone surveillance footage more efficient and more accurate, but as argued above Maven is an apparatus of recognition in a field of increasingly troubled identification. Defense One observes that before the system was deployed, the algorithms were 'trained' on thousands of hours of archived battlefield video captured by drones in the Middle East, yet differences in the trial area, explained Lt. Gen. Shanahan, Director of the project, posed problems that required further iterations. Moreover, Shanahan admits, 'There's some hard work behind the scenes that has to be done to first of all get that [video] cleaned up' in order to find 'the juicy parts where there's activity and then labeling the data' (Weisgerber 2017). Nonetheless, Shanahan insists, combining the designation of objects by drawing a box around them with georegistration of the object's coordinates 'is really increasing situational awareness' (Weisgerber 2017).

The discourse surrounding Project Maven overwhelmingly begs the question of the criteria by which 'objects' are identified as imminent threats. Just what constitutes the profile of an 'ISIS pickup truck' (Peniston 2017), and what were the 38 categories used by those who hand-labeled 150,000 images to form the initial training data set (Allen 2017)? Most pressingly, what does it mean to be living under drones, where the 
presence of what is seen by the US apparatus as 'abnormal activity' (Weisgerber 2017) might at any point trigger the identification of a threat and attack from weapons operating outside the range of one's own perception (Cavallaro et al 2012)? The project demands that we turn our attention to the highly problematic systems of classification by which categories like 'Islamic State militants' operating in Iraq, Syria, Somalia and other areas of US strategic interest are constituted. Even more urgently, it calls on us to question the premise that those categories are pre-existing and stable and that their members exist independently of the classificatory schemes that identify them, or of classification's violent consequences (see Bowker and Star 1999).

At some point down the road, according to Shanahan, the goal is to put the Project Maven technology 'at the edge,' on the drones themselves (Weisgerber 2017). Analyses of the use of remotely-controlled weapon systems should begin to make clear, however, the further problems inherent in the project of untethering these systems from their human controllers, which military technophiles take as the next logical step in the automation of warfare. Inescapably, the actual situations in which weapons are used are fraught with uncertainties. That these give rise to misrecognition on the part of human combatants could be - and has been - cited as the rationale for further automation of target identification. But if we look carefully at the circumstances surrounding documented incidents, it becomes clear that however tragically prone to misreading actual situations of contemporary 'irregular warfare' might be, the premise that they could be specified algorithmically is indefensible. There is no technological solution to this problem. 


\section{Conclusion}

Interrogating the Cold War logics of nuclear deterrence, Mackenzie (1990) has effectively opened up for us the black box of weapons targeting, and elucidated the contingent accomplishment of accuracy as a fact. In the case of strategic nuclear missiles, accuracy involved stabilising mathematical calculations of the trajectory that would be followed by a missile once released from its silo. The reinvention of accuracy in the case of so-called counterterrorism operations has worked to elide the difference between the precision with which a weapon, once fired, will strike its target, and the acts of identification of legitimate threats that targeting presupposes.

Insofar as the 'becoming weapon' of perception is tied to the identification of an Other as threat, this process long predates modern weaponry. A question for us to pursue, then, is just what are the particular apparatuses of recognition that comprise contemporary military discourses and technologies? How does the current 'threat' become recognisable, as specifically situated persons, embodied and emplaced? As military perceptions become more deeply imbricated with weaponry, it is also clear that the elaboration of weaponry is characterized not by a corresponding sophistication in military visualities, but rather by ever more reliance on still crude classificatory systems of racial/ethnic stereotyping and profiling. The cross hair of the weapon is deeply implicated in the objectification of its target. Yet as long as the 'accuracy' of the weapon is measured by the relation of lethal force to its designated object, the most vital question is left outside of the frame. Whether for a guided missile system, or the final actions of a suicide bomber, the fundamental question is how a target comes to be designated as such in the first instance, and within what regimes of historic injury and future accountability. 
The operational trope of 'situational awareness' is a core doctrine for military command and control. Taking a commitment to situational awareness seriously opens generative lines of critique - critique that needs to be taken seriously as well by those committed to military doctrine and operations (see de Goede forthcoming; Austin et al 2019). My aim in this paper has been to contribute to the wider body of scholarship devoted to understanding more deeply how technologies of militarism enroll their subjects and create their objects. The circuits that connect the apparatuses that I have discussed are the fantasies of recognition and the practices of dehumanisation that have shaped the politics of militarism since the advent of modern war fighting. These become ever more dangerous in the contemporary moment, as the figure of the imminent threat' is expanded into a horizon of anywhere and of endless war, and in that way actions taken in the name of defense by the US and its allies become a truly imminent threat to others. The promise of algorithmic warfare is a technological solution to the infamous 'fog of war,' taking the speed that automation enables as a proxy for the validity of the analyses that result. Rather than further accelerate the speed of warfighting, we need to challenge proclamations of an inevitable AI arms race and redirect investment to innovations in diplomacy and social justice that might truly deescalate the current threats - both geopolitical and planetary - to our collective security.

\section{Notes}

${ }^{\mathrm{i}}$ The literature here is large and growing. On security studies and targeting see for example Amoore 2019; Pugliese 2016; Kindervater 2016, 2017; Bousquet 2017; Wilcox 2015, 2017; Gregory 2018. Indicative references from STS include Chandler 2019; Gusterson 2016; Lindsay 2017; Parks and Kaplan 2017, Suchman et al 2017, and from feminist theory most immediately relevant to this discussion Butler 2010.

ii On the apparatus see also Agamben 2009, and on architectures of enmity see Shapiro 1997; Gregory 2004. For a cogent analysis of what they name 'apparatuses of distinction' see Perugini and Gordan 2017. 
iii On heterogeneous engineering see Law 1987; for my own mobilisation of that trope in the context of civil engineering see Suchman 2000.

${ }^{\text {iv }}$ A contemporaneous program, the Strategic Computing Initiative, promised to deliver AIbased systems to the three branches of the US armed services; for a critique see Ornstein et al 1983.

${ }^{\mathrm{v}}$ This incident was subject to a military investigation and documented in detail in an official DoD transcript of the radio transmissions and cockpit conversations. The latter were obtained by the Los Angeles Times through a Freedom of Information Act request, and have been the subject of a series of accounts and analyses. An early source is Cloud 2011; see also Chamayou 2014, Allinson 2015, Cockburn 2015, Gregory 2011; 2018, and Suchman 2015.

${ }^{v i}$ The friend/enemy difference has been widely and incisively critiqued within security studies and related fields; for a partial review of recent work see Suchman et al 2017; see also Perugini and Gordon 2017; Wilke 2017; Rogers 2018.

vii International Humanitarian Law is a body of customary law developed in the aftermath of WWII as part of the Geneva Conventions, aimed at establishing rules for humanitarian treatment under conditions of war. Rule number 1 of IHL is the Principle of Distinction, which states that 'The parties to the conflict must at all times distinguish between civilians and combatants. Attacks may only be directed against combatants. Attacks must not be directed against civilians' (ICRC 2004).

viii It is worth recalling that 2001 is the year of the first use of an armed drone by the US military in Afghanistan, a strike that killed a number of people while missing the one person, Taliban leader Mullah Omar, who was its target. As I was completing this article The Washington Post released The Afghanistan Papers (Whitlock 2019), a trove of government documents showing systematic misrepresentation of US operations in Afghanistan over a 18 year period. The papers include the statement of Douglas Lute, a three-star Army general who served as the White House's Afghan war czar during the Bush and Obama administrations,

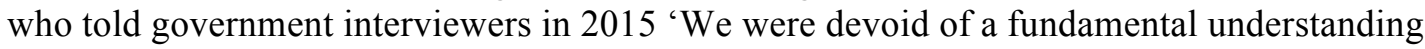
of Afghanistan — we didn't know what we were doing.'

${ }^{\text {ix }}$ Though note here that Bousquet et al. also observe approvingly that 'A productive turn [in IR and Security Studies] has recently begun to explore the agential power of weapons in and of themselves' $(2017,4))$. Without dismissing the importance of the materiality of weapons, the phrase 'in and of themselves' would seem in tension with their call for 'attention to how objects, ideologies, practices, bodies and affects get drawn into specific assemblages of violent intentionality' (1). For a nuanced analysis of the political agencies afforded by networked digital cameras see Saugmann forth.

${ }^{\mathrm{x}}$ Gregory (2018) rightly redirects attention from the operators of contemporary apparatuses of warfighting to 'the radical and devastating bioconvergence between the Hellfire missiles launched from those platforms and the bodies on the other side of the screens' (2018: 347). His most recent review of the 2010 incident in Uruzgan, Afghanistan emphasises the professional vision that produced the strike, but also works to recover a closer grasp for us as readers of those who were the strikes' targets. See also Hussain 2013; Wilcox 2017.

${ }^{x i}$ Those 'living under drones' (Cavallaro et al, 2012), Hussain observes, are unable to return the gaze that surveys them from above and beyond their range of vision, while the constant sound of the drone comprises an ongoing, and profoundly traumatising, threat. On sensoria of war see McSorley 2014; Näser-Lather 2015.

xii Metadata refers to information associated with a communication other than its content, e.g. all contacts by a targeted phone number, or geo-tracked travel through an area marked as the location of a targeted individual or group.

xiii The journal's masthead identifies its sponsor as the Association of Former Intelligence Officers.

xiv The reference to the defense agencies as the intelligence community's 'customer' articulates the further ellision of military and civilian imaginaries within the contemporary turn to a data-centric 'service economy'. See Amoore 2009. 
${ }^{x v}$ For a visualisation of these data see PitchInteractive 2013. For a powerful account of the 'uncounted' victims of Coalition forces air strikes in Iraq see Khan and Gopal 2017.

${ }^{x v i}$ On the problematic categories of 'children' and 'civilians' see Kinsella 2011; Wilke 2017.

xvii On the agency of Disclosing only that the trial system focuses on 38 classes of objects (Pellerin 2017), The Defense Department claims that all 5,000 documents related to Google's work on Project Maven are exempt from Freedom of Information Act law, as they possess 'critical infrastructure security information' (Biddle 2019).

${ }^{x v i i i}$ For a critical reading of the Principles see Suchman 2018.

${ }^{x i x}$ Schmidt retained the positions of Member of the Board and Technical Advisor to Alphabet at the same time that he took up his position as Chair of the Defense Innovation Board, characterized as an 'external' advisor to the DoD reporting to the Office of the Secretary of Defense. Schmidt is currently also Chair of the National Security Commission on AI, funded through the National Defense Authorization Act for fiscal 2019.

${ }^{x x}$ The reference here is to Air Force Lt. Gen. John N.T. 'Jack' Shanahan, Director of the project. It is worth noting that at the time that this address was given Schmidt presumably was aware of Google's contract on Project Maven, but there is no mention of that association in his comments.

\section{Acknowledgement}

My thanks to Rocco Bellanova, Linda Monsees, Katja Lindskov Jacobsen and participants in the workshops 'STS and International Relations: Politics, Practices, and Methods' (Bochum, Center for Advanced Internet Studies October 29-30, 2018) and 'Taking the Trouble: Inquiries into Science and Technology in Security Practice' (University of Amsterdam, 28-29 October 2019), as well as two anonymous reviewers, for their generative conversations and insightful comments on earlier versions of this paper.

\section{References}

Agamben, G. 2009. “What Is an Apparatus?” and Other Essays. Palo Alto: Stanford University Press.

Allinson, J. 2015. The necropolitics of drones. International Political Sociology 9(2): $113-127$.

Amoore, L. 2009. Algorithmic War: Everyday Geographies of the War on Terror. Antipode, 41(1), 49-69.

Austin, J. L., Bellanova, R. and Kaufmann, M. 2019. Doing and mediating critique: An invitation to practice companionship. Security Dialogue 50 (1):3-19.

Barad, K. 2007. Meeting the Universe Halfway: Quantum Physics and the Entanglement of Matter and Meaning. Durham, North Carolina: Duke University Press.

Bellanova, R., Monsees, L, Lindskov Jacobsen, K. forthcoming. Taking The Trouble: Science, Technology and Security Studies. Special Issue of Critical Studies on Security. 
Bell, M. 2013. Why Big Business and the NSA Sift through your data patterns. Channel 4 News, Nov 27. Accessed July 27, 2019 https://www.channel4.com/news/nsaspying-pattern-of-life-data-analysis-intelligence.

Bergen, M. 2018. Pentagon Drone Program is Using Google AI. Bloomberg. March 6. Accessed July 24, 2019 https://www.bloomberg.com/news/articles/2018-0306/google-ai-used-by-pentagon-drone-program-in-rare-military-pilot.

Biddle, S. 2019. Pentagon Says All of Google's Work on Drones Is Exempt From the Freedom of Information Act. The Intercept. March 25. Accessed July 26, 2019 https://theintercept.com/2019/03/25/google-project-maven-pentagon-foia/.

Bousquet, A. 2017. Lethal visions: the eye as function of the weapon. Critical Studies on Security, 5(1), 62-80.

Bousquet, A., Grove, J., and Shah, N. 2017. Becoming weapon: an opening call to arms. Critical Studies on Security, 5(1), 1-8.

Bowker, G., and Star, S. L. 1999. Sorting things out: classification and its consequences. Cambridge, Mass.: MIT Press.

Brennan, J. 2012. Speech to the Woodrow Wilson Center. Transcript accessed August 7, 2019 https://www.npr.org/2012/05/01/151778804/john-brennan-deliversspeech-on-drone-ethics.

Butler, J. 2010. Frames of War: When is Life Grievable? London and Brooklyn: Verso.

Cavallaro, J., Sonnenberg, S., and Knuckey, S. 2012. Living Under Drones: Death, Injury, and Trauma to Civilians From US Drone Practices in Pakistan. Stanford, New York: International Human Rights and Conflict Resolution Clinic, Global Justice Clinic.

Chamayou, G. 2014. A Theory of the Drone. New York: The New Press.

Chandler, K. 2019. Unmanning: How Humans, Machines and Media Perform Drone Warfare. New Brunswick, NJ: Rutgers University Press.

Cloud, D. 2011. Anatomy of an Afghan war tragedy. Los Angeles Times, April 10. Accessed August 6, 2019. http://www.latimes.com/news/nationworld/world/lafg-afghanistan-drone-20110410,0,200182.story

Cockburn, A. 2015. Kill Chain: The Rise of the High-Tech Assassins. New York: Henry Holt and Company.

Cole, D. 2014 'We kill people based on metadata'. The New York Review of Books, May 10. Accessed August 22019 www.nybooks.com/blogs/nyrblog/2014/may/10/we-kill-people-based-metadata/.

Confessore, N. and Rosenberg, M. 2018. 'Spy Contractor's Idea Helped Cambridge Analytica Harvest Facebook Data.' New York Times, March 27. accessed Dec 18, 2019. https:/www.nytimes.com/2018/03/27/us/cambridge-analyticapalantir.html

Conger, K. and Cameron, D. 2018. Google Is Helping the Pentagon Build AI for Drones. Gizmodo, March 3. Accessed July 24, 2019. https://gizmodo.com/google-is-helping-the-pentagon-build-ai-for-drones1823464533.

Davidson, J. 2011. Lifting the Fog of Peace: How Americans Learned to Fight Modern War. Ann Arbor: University of Michigan Press.

de Goede, M. forthcoming. Engagement All the Way Down. Special issue of Critical Studies on Security. 
Dostal, B.C. 2001. Enhancing Situational Understanding through the Employment of Unmanned Aerial Vehicles. Global Security.org. accessed August 6, 2019. https://www.globalsecurity.org/military/library/report/call/call 01-18 ch6.htm

Deputy Secretary of Defense. 2017. Establishment of an Algorithmic Warfare Cross Functional Team (Project Maven). Memorandum dated April 26. accessed July 24, 2019 https://www.govexec.com/media/gbc/docs/pdfs_edit/establishment of the awcf t project maven.pdf.

Endsley, M.R. 1995. Toward a theory of situation awareness in dynamic systems. Human Factors. 37 (1): 32-64.

Fang, L. 2018. Google Is Quietly Providing AI Technology for Drone Strike Targeting Project. The Intercept, March 6. Accessed July 26, 2019 https://theintercept.com/2018/03/06/google-is-quietly-providing-ai-technologyfor-drone-strike-targeting-project/.

Fang, L. 2019. Defense Tech Startup Founded by Trump's Most Prominent Silicon Valley Supporters Wins Secretive Military AI Contract. The Intercept, March 9. Accessed Dec 20, 2019 https://theintercept.com/2019/03/09/anduril-industriesproject-maven-palmer-luckey/

Fortune Staff. 2018. 3 Ways AI is Making You Safer. Fortune, October 22. Accessed August 7, 2019. https://fortune.com/2018/10/22/artificial-intelligence-aidefense-weapons/.

Google. nd. Artificial Intelligence at Google: Our Principles. Accessed July 31, 2019 https://ai.google/principles/.

Green, D. 2018. Incorporating Google's AI Principles into Google Cloud. June 7. accessed July 23, 2019 https://www.blog.google/products/googlecloud/incorporating-googles-ai-principles-google-cloud/.

Greene, T. 2019. Report: Palantir took over Project Maven, the military AI program too unethical for Google. The Next Web, Dec. 11. Accessed Dec 20, 2019. https://thenextweb.com/artificial-intelligence/2019/12/11/report-palantir-tookover-project-maven-the-military-ai-program-too-unethical-for-google/

Gregory, D. 2004. The Colonial Present. Oxford: Blackwell.

Gregory, D. 2011. From a View to a Kill: Drones and Late Modern War. Theory, Culture \& Society, 28(7-8), 188-215.

Gregory, D. 2014. The God trick and the administration of military violence. Geographical Imaginations, April 26. Accessed August 6, 2019. https://geographicalimaginations.com/2014/04/26/the-god-trick-and-theadministration-of-military-violence/

Gregory, D. 2015. Moving targets and violent geographies. In H. Merrill \& L. M. Hoffman (Eds.), Spaces of Danger: Culture and Power in the Everyday (pp. 256-296). Atlanta: University of Georgia.

Gregory, D. 2018. Eyes in the sky - bodies on the ground. Critical Studies on Security, 6 ( 3), 347-358.

Gusterson, H. 2016. Drone: Remote control warfare. Cambridge, MA: MIT Press.

Hussain, N. 2013. The Sound of Terror: Phenomenology of a Drone Strike. Boston Review. October 16. Accessed August 3, 2019. http://www.bostonreview.net/world/hussain-drone-phenomenology.

ICRC. 2004. What is International Humanitarian Law? Accessed August 7, 2019 https://www.icrc.org/eng/assets/files/other/what_is_ihl.pdf. 
Kahn, A. and Gopal, A. 2017. The Uncounted. New York Times Magazine, Nov 16. Accessed Dec 21, 2019. https://www.nytimes.com/interactive/2017/11/16/magazine/uncounted-civiliancasualties-iraq-airstrikes.html.

Kaplan, C. 2006. Mobility and War: The Cosmic View of US 'Air Power'. Environment and Planning A, 38(2), 395-407.

Kindervater, K. H. 2016. The Emergence of Lethal Surveillance: Watching and Killing in the History of Drone Technology. Security Dialogue, 47(3), 223-238.

Kindervater, K. H. 2017. The technological rationality of the drone strike. Critical Studies on Security, 5(1), 28-44.

Kinsella, H. 2011. The Image before The Weapon: A Critical History of the Distinction between Combatant and Civilian. Ithaca, NY: Cornell University Press.

Law, J. 1987. Technology and Heterogeneous Engineering: The Case of Portuguese Expansion. In W. Bijker, T. Hughes, \& T. Pinch (Eds.), The Social Construction of Technological Systems (pp. 111-134). Cambridge, MA: MIT.

Lindsay, J. R. 2017. Target Practice: Counterterrorism and the Amplification of Data Friction. Science, Technology and Human Values, 42(6), 1061-1099

Long, L. 2013. Activity Based Intelligence: Understanding the Unknown. The Intelligencer, Fall/Winter, 7-15.

Mackenzie, D. 1990. Inventing Accuracy: A Historical Sociology of Nuclear Missile Guidance. Cambridge, MA: MIT press.

McSorley, K. 2014. Towards and embodied sociology of war. The Sociological Review, 62(2), 107-128.

Morris, E. 2003. The Fog of War: Eleven Lessons from the Life of Robert S. McNamara. Sony Pictures.

Näser-Lather, M. 2015. Experiencing war. The reconfiguration of the senses among German soldiers deployed to Afghanistan. Critical Military Studies, 4(3), 227243.

Ornstein, S., Smith, B. C., and Suchman, L. 1983. Strategic Computing. Bulletin of the Atomic Scientists, 11-15.

Owens, B., Offley, E. 2000. Lifting the Fog of War. New York: Farrar, Strauss and Giroux.

Parks, L., and Kaplan, C. (Eds.). 2017. Life in the Age of Drone Warfare. Durham and London: Duke University Press.

Parnas D.L. 1985. Software aspects of strategic defense systems. Communications of the ACM. 28 (12): 1326-35.

Pellerin, C. 2017. Project Maven to Deploy Computer Algorithms to War Zone by Year's End. US Department of Defense, July 21. Accessed July 24, 2019https://dod.defense.gov/News/Article/Article/1254719/project-maven-todeploy-computer-algorithms-to-war-zone-by-years-end/.

Peniston, B. 2017. How Will the Pentagon Create Its AIs? The Algorithmic Warfare Team is Charting a Path. Defense One. July 13. Accessed July 24, 2019 https:/www.defenseone.com/technology/2017/07/artificial-intelligencepentagon/139402/.

Perugini, N and Gordon, N. 2017. Distinction and the Ethics of Violence: On the Legal Construction of Liminal Subjects and Spaces. Antipode, online pub, 1-21.

PitchInteractive. 2013. Out of Sight, Out of Mind. Accessed August 7, 2019 http://drones.pitchinteractive.com/ 
Pugliese, J. 2016. Death by Metadata: The Bioinformationalisation of Life and the Transliteration of Algorithms to Flesh. In Security, Race, Biopower: Essays on Technology and Corporeality, edited by H. Randell-Moon and R. Tippet, 3-20. London: Palgrave.

Rogers, A. 2018. Evil ${ }^{\text {TM }}$ - Islamic State, conflict-capitalism, and the Geopolitical Uncanny. Critical Studies on Security, 6(1), 118-135.

Saugmann, R. forthcoming. The security captor, captured: Digital cameras, visual politics and material semiotics. Special issue of Critical Studies on Security.

Scahill, J. 2016. The Assassination Complex. New York: Simon and Schuster.

Scahill, J., Greenwald, G. 2014. The NSA's Secret Role in the U.S. Assassination Program. The Intercept, February 9. Accessed August 7, 2019 https://theintercept.com/2014/02/10/the-nsas-secret-role/.

Scharre, P., Cho, A., Allen, G., and Schmidt, E.. 2017. Eric Schmidt Keynote Address at the Center for a New American Security Artificial Intelligence and Global Security Summit. November 13. Accessed July 26, 2019 https://www.cnas.org/publications/transcript/eric-schmidt-keynote-address-atthe-center-for-a-new-american-security-artificial-intelligence-and-globalsecurity-summit.

Shapiro, M. J. 1997. Violent Cartographies: Mapping Cultures of War. Minneapolis: University of Minnesota Press.

Shapiro, M. J. 2013. Encounters: war's becoming Subjects. Critical Studies on Security, 1(1). 136-141.

Smith, B. C. 1993. Limits of Correctness in Computers. In T. Colburn, J. Fetzer, \& T. Rankin (Eds.), Program Verification: Fundamental Issues in Computer Science (pp. 275-293). Dordrecht, the Netherlands: Kluwer Academic Publishers.

Suchman, L. 2000. Organizing Alignment: A case of bridge-building. Organization, $7(2), 311-327$.

Suchman, L. 2015. Situational Awareness: Deadly bioconvergence at the boundaries of bodies and machines. Media Tropes, V(1), 1-24.

Suchman, L. 2018. Corporate Accountability. Robot Futures blogpost, November 24. accessed July 31, 2019 https://robotfutures.wordpress.com/2018/06/10/corporate-accountability/.

Suchman, L., Follis, K., and Weber, J. 2017. Tracking and Targeting: Sociotechnologies of (In)security. Science, Technology and Human Values, 42(6), 983-1002.

Suchman, L., Irani, L., and Asaro, P.. 2018. Google's march to the business of war must be stopped. The Guardian, May 16. Accessed July 26, 2019 https://www.theguardian.com/commentisfree/2018/may/16/google-businesswar-project-maven.

von Clausewitz, C. 1989/1832. On War. Princeton: Princeton University Press.

Weisgerberger, M. 2017. The Pentagon's New Algorithmic Warfare Cell Gets Its First Mission: Hunt ISIS. Defense One. May 14. Accessed July 24, 2019 https:/www.defenseone.com/technology/2017/05/pentagons-new-algorithmicwarfare-cell-gets-its-first-mission-hunt-isis/137833/?oref=d1-in-article.

Whitlock, Craig. 2019. The Afghanistan Papers A secret history of the war. Washington Post, Dec 9. Accessed Dec 12, 2019

https://www.washingtonpost.com/graphics/2019/investigations/afghanistanpapers/afghanistan-war-confidential-documents/ 
Wilcox, Lauren. 2015. Drone warfare and the making of bodies out of place. Critical Studies on Security, 3(1), 127-131.

Wilcox, Lauren. 2017. Embodying algorithmic war: Gender, race, and the posthuman in drone warfare. Security Dialogue, 48(1), 11-28.

Wilke, C. 2017. Seeing and Unmaking Civilians in Afghanistan: Visual Technologies and Contested Professional Visions. Science, Technology and Human Values, 42(6), 1031-1060. 